\title{
Implementing Backward Chaining Method in Expert System to Detect and Treat Rice, Chilli, and Corn Plant's Pests and Diseases
}

\author{
Anton Muhibuddin ${ }^{1}$, Primaadi Airlangga ${ }^{2}$, M. Mirza Sulthoni ${ }^{3}$, Aries Budi Wicaksana ${ }^{4}$ \\ ${ }^{1,2,3,4}$ Faculty of Information Technology Universitas K.H. A. Wahab Hasbullah Indonesia
}

\section{ARTICLE INFORMATION}

Received: March 20, 2018

Revised: September 5, 2018

Available online: September 29, 2018

\section{KEYWORDS}

Expert System, Backward Chaining, Disease, pest, corn, chilli, rice.

\section{CORRESPONDENCE}

E-mail: unwaha.primaadi@yahoo.com

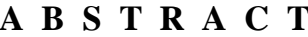

Indonesia is an agrarian country which most of it's citizens are farmer. There are various kind of decent plants to grow in Indonesia but most of them plant rice, corn, wheat, and sago as staple food. There other plants that is consumed not as main food but as subsidiaries, one of them are chilli pepper. Abundant variety of vegetation in Indonesia means that there are also many type of pests and diseases. An agriculture expert is needed to identify plant's diseases and pest correctly. Meanwhile, the number of agriculture experts is insufficient to help massive amount of farmer whom have trouble in agriculture. This problem can be solved by using Expert System where farmers can detect the problem on their plants and finding treatment to cure their plants correctly them self. This research is mean to develop an Expert System Application in agriculture to identify diseases and pests based on their symptoms especially rice, chilli, and corn plants. This Expert System is based on web program using Backward Chaining Inversion which is deemed necessary to solve the case study's problem. Responsive Web Based System can be accessed by user or client from many devices especially their smart phoneto hel diagnose disease that occurs to their plant, moreover, to solve the low rate of expert on agriculture.

\section{PENDAHULUAN}

Indonesia adalah negara dimana sebagian besar penduduknya mengkonsumsi beras dan jagung sebagai makanan pokok dan mengolah cabai menjadi pelengkap makanan pokok yang disandingkan dengan lauk pauk. Konsumsi yang besar ini tidak ditunjang dengan produksi yang tinggi mengakibatkan tidak terpenuhinya kebutuhan bahan pangan secara nasional. Rendahnya produksi disebabkan oleh banyak hal, salah satunya gagalnya panen dikarenakan hama dan penyakit yang menyerang tanaman tidak bisa ditanggulangi secara efektif dan efisien.

Pada saat ini, hampir semua proses diagnosis hama dan penyakit tanaman di Indonesia masih dilakukan secara manual dengan cara pakar melihat langsung ladang jagung yang terserang hama atau penyakit lalu melihat gejala yang tampak pada tanaman dan mendiagnosis hama dan penyakit yang sedang menyerang tanaman jagung tesebut. Hal ini dirasa kurang tepat karena proses di mana petani harus melaporkan kepada pakar atau kantor dinas setempat memakan waktu. Begitu pula untuk mendatangi kebun petani, pakar memerlukan waktu dan mungkin saja keadaan tanaman yang terserang hama dan penyakit tersebut bisa bertambah parah, sehingga para petani mengalami banyak kerugian karena serangan tersebut. Serangan hama dan penyakit tersebut dapat teratasi dengan cepat apabila petani mampu mengidentifikasi jenis hama dan penyakit yang menyerangnya secara cepat dan tepat berdasarkan pada gejalagejala yang muncul. Sehingga dampak yang ditimbulkan bisa diminimalisir sedini mungkin.

Dengan adanya sistem informasi, pengidentifikasian suatu masalah seperti gejala-gejala yang terjadi pada dunia pertanian akan lebih mudah dan cepat sehingga dapat dilakukan langkah- langkah penanggulangan dengan lebih cepat pula. Pada dunia ilmu komputer, tindakan yang cepat dan tepat dalam mengidentifikasi hama dan penyakit tersebut dapat diwujudkan melalui pembuatan sistem pakar. Tujuan utama sistem pakar bukan untuk mengganti kedudukan seorang pakar, tetapi memasyarakatkan pengetahuan dan pengalaman seorang pakar. Sistem pakar merupakan sistem yang berusaha mengadopsi pengetahuan manusia ke komputer, agar komputer dapat menyelesaikan masalah seperti yang biasa dilakukan oleh para ahli (Pusadan,2015). Sistem pakar biasanya digunakan untuk konsultasi, melakukan analisis dan diagnosis, membantu pengambilan keputusan, dan lain-lain.

Berdasarkan latar belakang diatas, penulis bermaksud membangun sistem informasi berbasis web yang dapat mengidentifikasi hama dan penyakit pada tanaman padi, jagung, dan cabai dengan metode backward chaining.

\section{LANDASAN TEORI}

Kecerdasan buatan adalah suatu ilmu yang mempelajari cara membuat komputer melakukan sesuatu seperti yang dilakukan oleh manusia. Definisi lain diungkapkan oleh Kecerdasan buatan (artificial intelligence) merupakan kawasan penelitian, aplikasi dan instruksi yang terkait dengan pemrograman komputer untuk melakukan sesuatu hal yang dalam pandangan manusia adalah cerdas. 
Ada tiga tujuan kecerdasan buatan, yaitu: membuat komputer lebih cerdas, mengerti tentang kecerdasan, dan membuat mesin lebih berguna. Yang dimaksud kecerdasan adalah kemampuan untuk belajar atau mengerti dari pengalaman, memahami pesan yang kontradiktif dan ambigu, menanggapi dengan cepat dan baik atas situasi yang baru, menggunakan penalaran dalam memecahkan masalah serta menyelesaikannya dengan efektif (Winston dan Prendergast, 1994).

Sistem pakar adalah aplikasi berbasis komputer yang digunakan untuk menyelesaikan masalah sebagaimana yang dipikirkan oleh pakar. Pakar yang dimaksud disini adalah orang yang mempunyai keahlian khusus yang dapat menyelesaikan masalah yang tidak dapat diselesaikan oleh orang awam (Kusrini, 2008, h. 3). Biasanya sistem pakar hanya digunakan untuk memecahkan masalah yang memang sulit untuk dipecahkan dengan pemrograman biasa, mengingat biaya yang diperlukan untuk membuat sistem pakar jauh lebih besar dari pembuatan sistem biasa (Kusrini, 2006 : 12).

\section{METODE PENELITIAN}

Adapun metode penelitian yang penulis gunakan adalah sebagai berikut :

\section{Pengumpulan Data}

Metode pengumpulan data yang dipakai adalah sebagai berikut :

a. Studi Literatur

Tahapan ini dilakukan dengan mempelajari sumbersumber atau buku buku referensi yang berkaitan dengan sistem pakar dan hama tanaman padi, cabai, serta jagung.

b. Wawancara

Tahapan ini dilakukan dengan penelitian lapangan dan wawancara pada pihak-pihak yang berkompeten yang dapat memberikan informasi yang dibutuhkan dalam pengerjaan penelitian. Beberapa ahli yang dapat ditemui di sekitar kawasan penelitian memberikan masukan-masukan tentang jenis hama, cara-cara penanggulangan, juga dalam hal pengoprasian sebuah applikasi agar mudah digunakan oleh petani.

\section{Analisis Data}

Tahap ini dilakukan analisis kebutuhan sistem dan menjadi dasar untuk perancangan sistem, seperti pengolahan data spesifikasi hama dan penyakit tanaman jagung.

\section{Perancangan Perangkat Lunak}

Tahapan ini dilakukan dengan membuat gambaran sistem baik berupa diagram alir (flowchart), masukan, keluaran, DFD (Data Flow Diagram),.

\section{Implementasi Aplikasi}

Tahapan ini dilakukan dengan melakukan penerapan rancangan sistem yang dibuat ke dalam suatu program.

\section{Pengujian Aplikasi}

Tahapan ini dilakukan dengan melakukan pengujian terhadap perangkat lunak yang telah dibuat untuk mengetahui kesalahan dan memperbaiki kesalahan yang ada.

\section{Dokumentasi dan Penulisan Laporan}

Melakukan pembuatan dokumentasi sistem mulai dari tahap awal hingga akhir pengujian sistem, dan menulis laporan.

\section{PEMBAHASAN}

Dalam pembuatannya, sistem pakar hama dan penyakit tanaman padi, jagung dan cabai ini menggunakan barkward chaining dimana jenis hama dan penyakit ditentukan lebih dahulu baru kemudian dilakukan pengecekan dan perhitungan gejalagejala yeng berhubungan dengan penyakit tersebut.

Beberapa hal yang sifatnya deskripsi dan pelengkap juga ditambahkan ke dalam applikasi ini karena bila algoritma backward chaining untuk mengetahui hama berdiri sendiri, applikasi ini kurang bermanfaat karena sulit digunakan oleh orang awam. Fitur-fitur lainnya antara lain gambar dari gejala, cara penanganan penyakit, dan pencatatan hasil pencarian penyakit.

Adapun sebagian bentuk perancangan form yang dibutuhkan adalah sebagai berikut :

\section{Rancangan Menu Beranda}

Pada menu ini berisikan tampilan pertama yang dilihat oleh pengguna ketika pertama kali membuka program

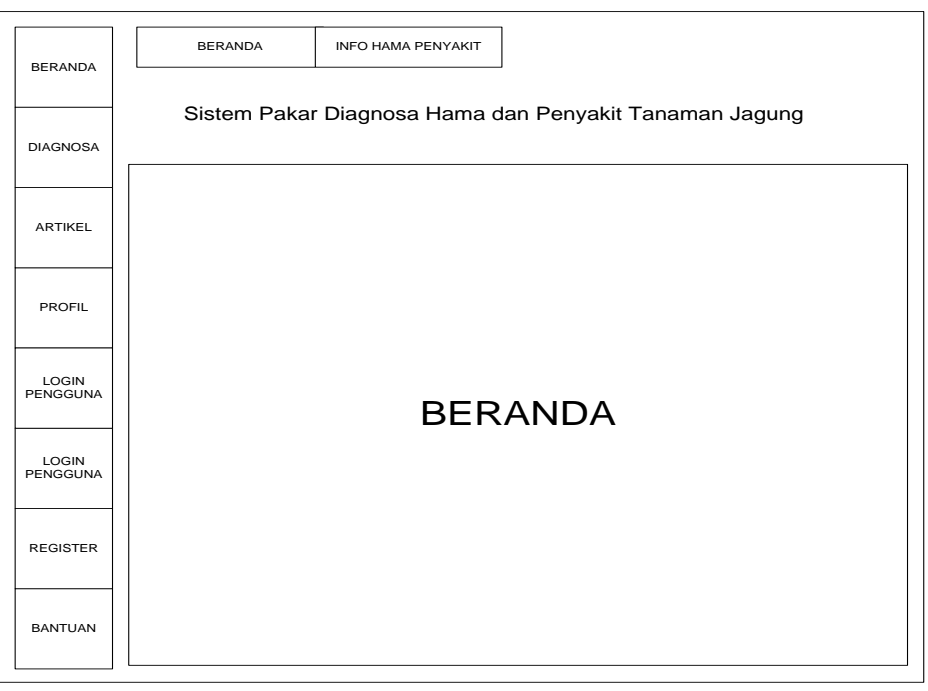

Gambar 1: Perancangan Menu Beranda

\section{Rancangan Menu Registrasi}

Sebelum menjalankan program tersebut pengguna diharuskan mendaftarkan diri untuk mendapatkan user dan password, untuk itu pengguna diharuskan mengisi identitas diri mereka 


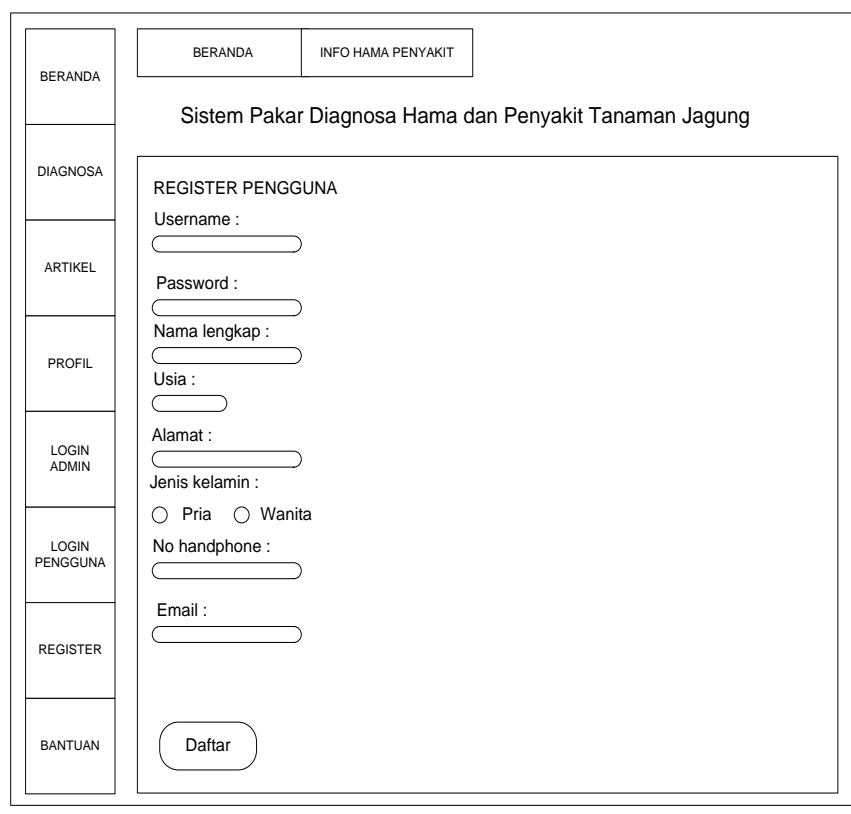

Gambar 2: Perancangan Menu Registrasi

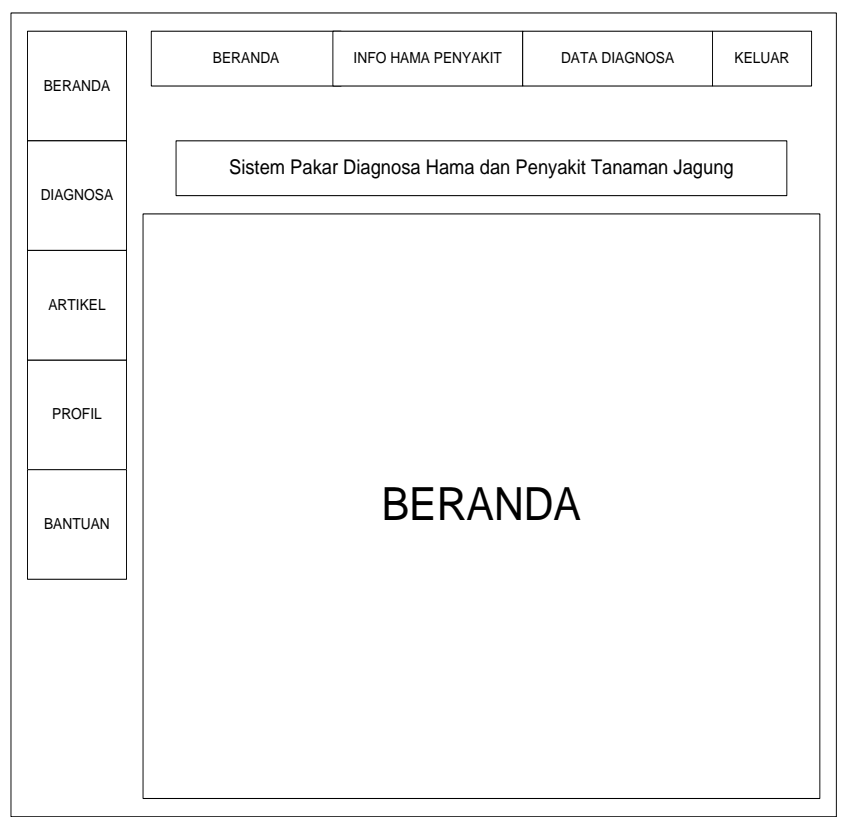

Gambar 3: Perancangan Menu Pengguna

\section{Rancangan Menu Hasil Diagnosa}

Setelah penguna melakukan registrasi dan mendapatkan user dan password, pengguna diharapkan login, setelah melakukan login pengguna dapat langsung melakukan diagnose dan dari diagnose itu pengguna dapat mendapatkan laporan dari diagnose yang sudah dilakukannya.

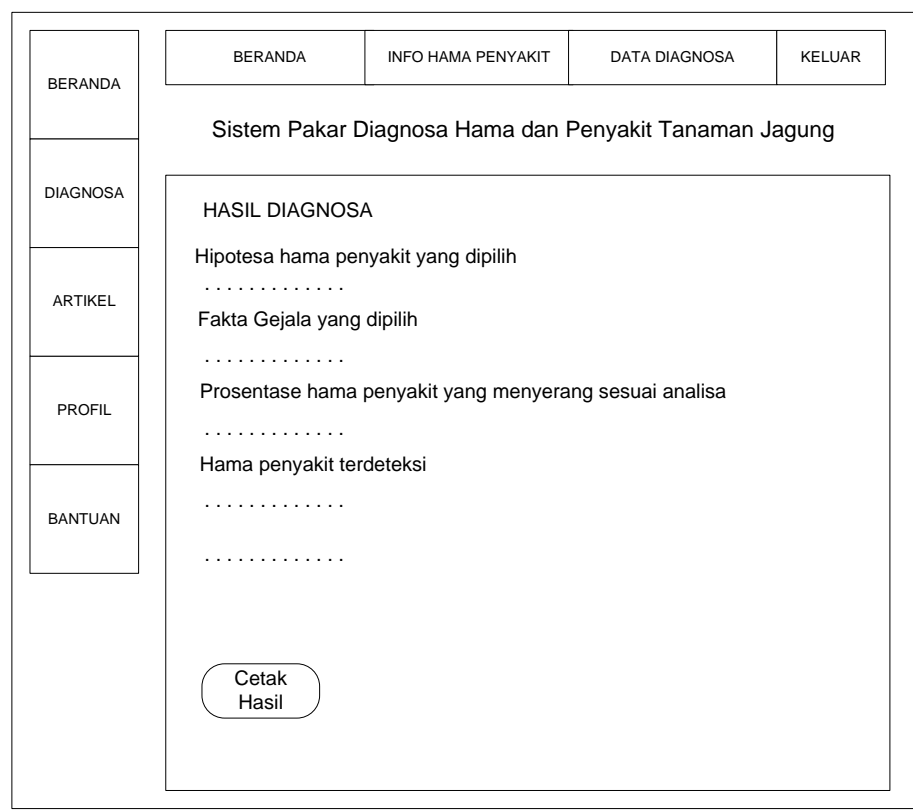

Gambar 4: Perancangan Menu Hasil Diagnosa

\section{Hasil Interface Aplikasi}

Setelah dilakukan perancangan interface, dilakukan pengujian untuk melihat apakah hasil perancangan dapat berjalan sesuai harapan. Adapun sebagian hasil yang didapatkan adalah sebagai berikut :

\section{Halaman Beranda}

Halaman beranda adalah tampilan ketika pengguna pertama kali membuka program tersebut.

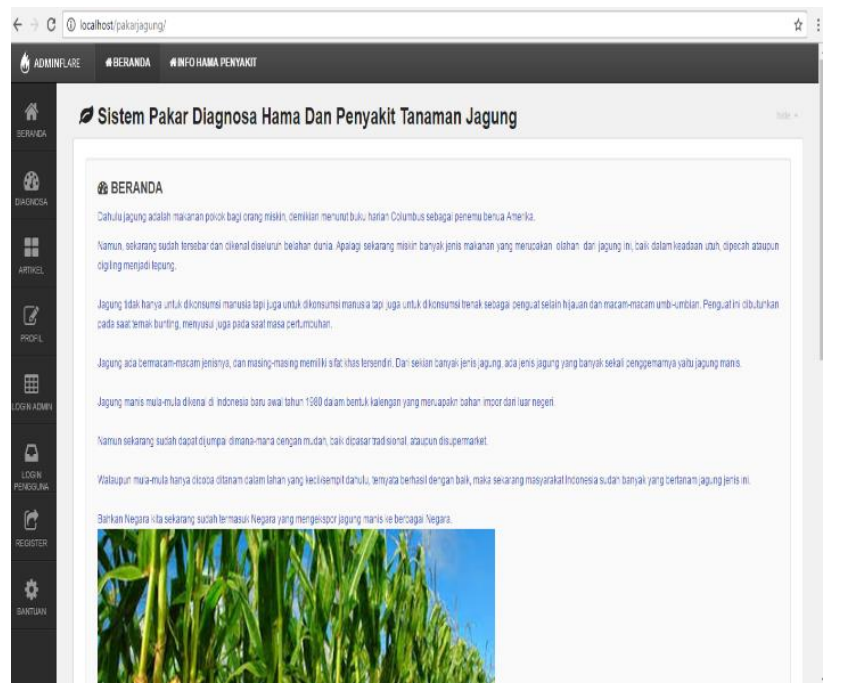

Gambar 5: Halaman Menu Beranda 


\section{Halaman Menu Registrasi}

Halaman ini berfungsi untuk registrasi pengguna baru yang belum memilik user dan password.

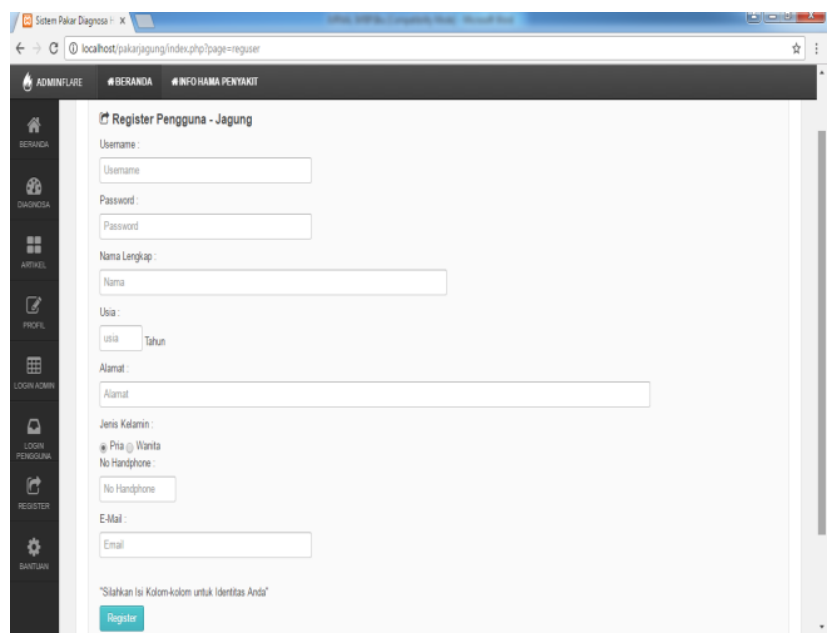

Gambar 6 : Halaman Menu Registrasi

\section{Halaman Menu Login Pengguna}

Pada halaman ini pengguna yang melakukan registrasi dan mendapatkan user dan password dapat langsung login ke program.

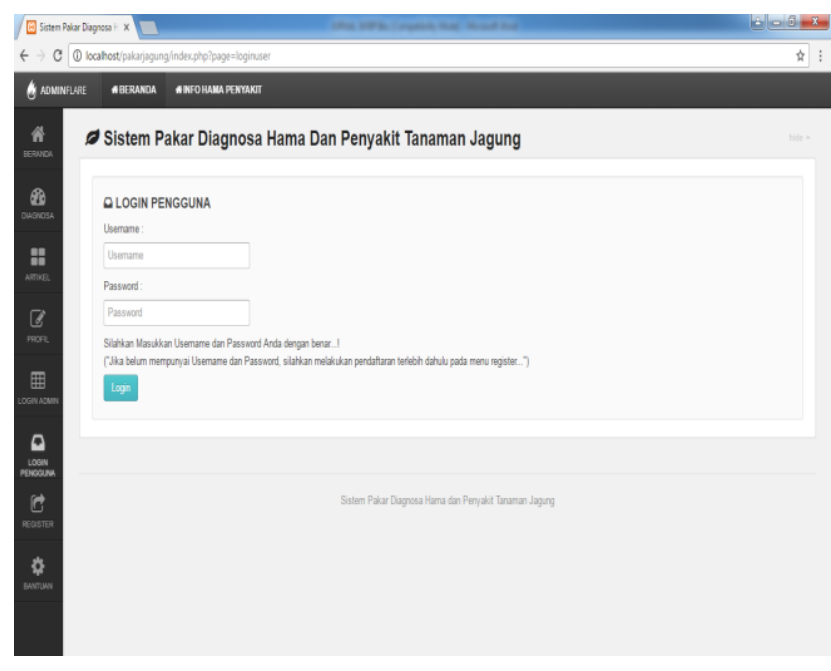

Gambar 6: Halaman Menu Registrasi

\section{Halaman Menu Hasil Diagnosa}

Pada menu ini akan terlihat jenis penyakit, nama penyakit dan cara mengatasinya dalam menu ini pengguna dapat mencetak hasil diaagnosanya.

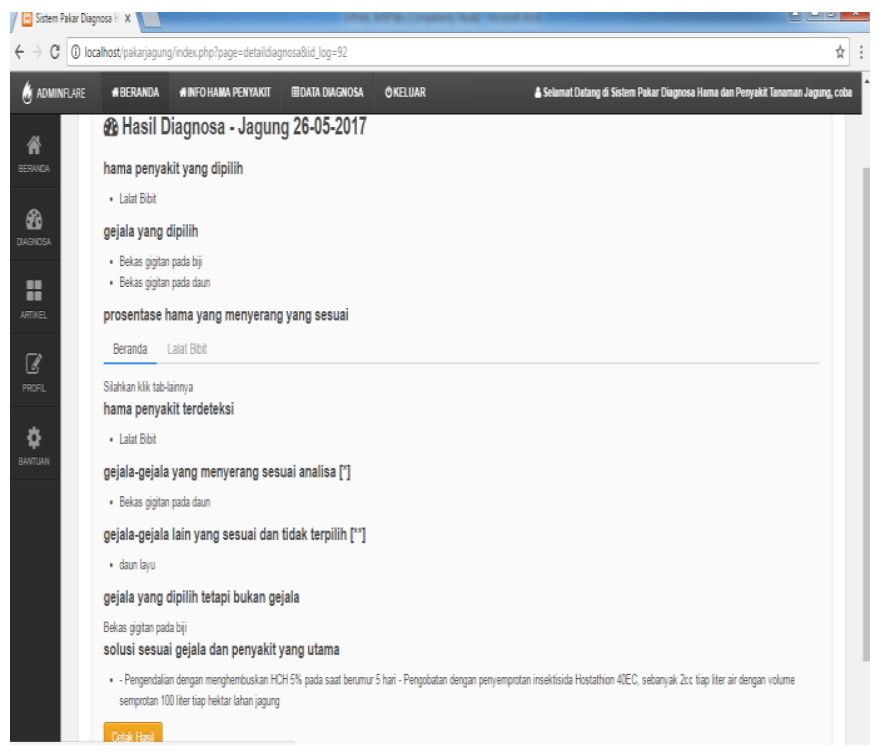

Gambar 7: Halaman Menu Hasil Diagnosa

\section{Uji Coba Program}

Uji coba program Sistem pakar hama dan penyakit tanaman jagung dilakukan dengan menggunakan metode Black Box Testing. Metode Black Box Testing merupakan pengujian program yang mengutamakan pengujian terhadap kebutuhan fungsi dari suatu program. Tujuan dari metode Black Box Testing ini adalah untuk menemukan kesalahan fungsi pada program

Tabel 1: Pengujian Black box Pada Menu Registrasi

\begin{tabular}{|c|c|c|}
\hline Sekenario Pengujian & $\begin{array}{ll}\text { Hasil } & \text { Yang } \\
\text { diharapkan } & \end{array}$ & Kesimpulan \\
\hline $\begin{array}{l}\text { Mengisi semua } \\
\text { identitas diri dengan } \\
\text { benar, Klik registrasi }\end{array}$ & \begin{tabular}{lr} 
Sistem & menerima \\
registrasi & dan \\
langsung diarahkan \\
\multicolumn{2}{l}{ ke menu login }
\end{tabular} & Valid \\
\hline $\begin{array}{l}\text { Mengisi remua } \\
\text { identitas diri dengan } \\
\text { tidak lengkap, Klik } \\
\text { registrasi }\end{array}$ & $\begin{array}{lr}\text { Sistem } & \text { Akan } \\
\text { menampilkan pesan “ } \\
\text { untuk } & \text { mengisi } \\
\text { identitas } & \text { yang } \\
\text { kosong” } & \end{array}$ & Valid \\
\hline
\end{tabular}


Tabel 2: Pengujian Black box Pada Menu Login Pengguna

\begin{tabular}{|c|c|c|}
\hline $\begin{array}{l}\text { Sekenario } \\
\text { Pengujian }\end{array}$ & $\begin{array}{l}\text { Hasil Yang } \\
\text { diharapkan }\end{array}$ & Kesimpulan \\
\hline $\begin{array}{l}\text { Mengisi } \\
\text { Username dan } \\
\text { Password } \\
\text { dengan benar, } \\
\text { Klik Login }\end{array}$ & $\begin{array}{l}\text { Sistem } \\
\text { menerima login } \\
\text { dan masuk ke } \\
\text { menu pengguna }\end{array}$ & Valid \\
\hline $\begin{array}{l}\text { Mengisi } \\
\text { Username dan } \\
\text { Password tidak } \\
\text { benar (Salah), } \\
\text { Klik Login }\end{array}$ & $\begin{array}{l}\text { Sistem Akan } \\
\text { menampilkan } \\
\text { pesan " Login } \\
\text { Gagal" }\end{array}$ & Valid \\
\hline
\end{tabular}

Tabel 3: Pengujian Black box Pada Menu Diagnosa

\begin{tabular}{|l|l|c|}
\hline $\begin{array}{l}\text { Sekenario } \\
\text { Pengujian }\end{array}$ & $\begin{array}{l}\text { Hasil Yang } \\
\text { diharapkan }\end{array}$ & Kesimpulan \\
\hline $\begin{array}{l}\text { Mengisi semua } \\
\text { alur diagnosa, Klik } \\
\text { selanjutnya }\end{array}$ & $\begin{array}{l}\text { Sistem menampilkan } \\
\text { Hasil Diagnosa }\end{array}$ & Valid \\
\hline $\begin{array}{l}\text { Tidak mengisi alur } \\
\text { diagnosa, Klik } \\
\text { Selanjutnya }\end{array}$ & $\begin{array}{l}\text { Sistem Akan } \\
\text { menampilkan pesan } \\
\text { "EROR,Data masih } \\
\text { Kosong” }\end{array}$ & Valid \\
\hline
\end{tabular}

\section{KESIMPULAN}

Sistem Pakar Diagnosa Hama/ Penyakit pada Tanaman Padi, Jagung dan Cabai memiliki database sebagai penyimpanan data yang dapat digunakan untuk pencarian data lebih cepat dan dapat digunakan dalam pembuatan laporan tertentu. Setiap klien yang telah teregistrasi dapat langsung menggunakan layanan diagnosa. Setelah proses diagnosa maka akan muncul hasil secara detail tentang penyakit atau hama yang sedang terjadi. Sistem pakar diagnosa hama dan penyakit padi, jagung dan cabai ini terdiri dari dua menu, yaitu menu untuk admin dan menu untuk pengguna. Pada menu admin meliputi menu beranda, artikel, data hama penyakit, data gejala, data solusi, daftar pengguna, laporan diagnosa, aturan dan halaman statis. Pada menu pengguna meliputi menu beranda, diagnosa, artikel, profil, bantuan, info hama penyakit, dan data diagnosa. Sistem pakar diagnosa hama dan penyakit padi, jagung, dan cabai menggunakan pengetahuan berbasis aturan memalui mesin inferensi backward chaining (penalaran mundur). Sistem pakar diagnosa hama dan penyakit menghasilkan solusi pencegahan dan pengendalian yang didapat dari perhitungan hipotesa hama penyakit, lalu fakta gejala yang dialami, kemudian dicocokkan dengan aturan dan akan menghasilkan solusi pencegahan dan pengendalian sesuai dengan relasi antar ham a penyakit, gejala dan solusi tersebut.

\section{REFERENSI}

[1] Anhar, 2010. Panduan Menguasai PHP dan MySQL Secara Otodidak. Jakarta : Media Kita.

[2] Arhami, M. 2005. "Konsep Dasar Sistem Pakar". Yogyakarta : Andi Offset.

[3] Budi Raharjo, Imam Heryanto dan Endang. 2010. Modul Pemrograman WEB HTML,PHP dan MySQL. Modula : Bandung.

[4] Harahap, S. I., Tjahjono 1989. "Panyakit dan Hama Tanaman Padi ”. PT.Penebar Swadaya. Jakarta.

[5] Hidayat, S. 2011. "Aplikasi Untuk Mendeteksi Jenis Penyakit Pada tanaman Tebu dan Penanganannya Berbasis Web". Jurnal Skripsi / TA. Bandung : UNIKOM.

[6] Honggowibowo, A. S. 2012. "Sistem Pakar Berbasis web Untuk Mendiagnosa Penyakit Tanaman Jagung dan Cara Penanggulangannya Secara Kimia Teknis". Yogyakarta : Sekolah Tinggi Teknologi Adisutjipto.

[7] Iriani, S. 2015. "Penerapan Metode Backward Chaining Pada SIstem Pakar Diagnosa Penyakit Tulang Manusia”. IJNS : Volume.4 No.1 Pacitan : STKIP PGRI.

[8] Nurhayati. 2012. Virus Penyebab Penyakit Tanaman. Unsri Press. Palembang.

[9] Kusrini. 2006. Sistem Pakar Teori Dan Aplikasi. Yogyakarta: CV. Andi Offset. 